\section{Belov I., Vahischevich M., Dedov 0.}

\title{
NUMERICAL AND EXPERIMENTAL INVESTIGATION OF THE CAVE PASSAGE MODEL
}

Об’єктом досліджень є грунтова модель ділянки печери, що апроксимує частину підземної споруди Києво-Печерської лаври (Київ, Україна). Тривала експлуатачія підземних історичних споруд в стиснених умовах при 100 \% вологості та під дією агресивних впливів внутрішніх $і$ зовнішніх чинників призводить до вичерпання їх конструктивної надійності. При реставрацї історичних об’єктів є доцільним об’єднання залишкових ресурсів разом з локальними конструктивними підкріпленнями. Завдяки иій концепщї відновлюється первісний стан, і конструкцї можуть ще довгий час виконувати свої функцї в умовах існуючого середовища. Такі підсилення створюють міщні і жорсткі осередки, які об'єднують об'єкт в єдине ціле.

Означений підхід був апробований шляхом натурного випробування моделі фрагменту підземного ходу Дальніх печер, виконаної із супіску в натуральну величину. Дослідження проводилися на базі Випробувального центру будівельних конструкцій Київького національного університету будівництва $і$ архітектури в період з 2012 по 2019 рр. Розроблена методика підсилення грунтового масиву внутрішнім базальтовим армуванням - плоскими каркасами - була використана під час реставрацї окремих ділянок підземних споруд Києво-Печерської лаври. Водночас з натурними випробуваннями виконувалися і чисельні дослідження відповідної математичної моделі. Чисельно-експериментальний підхід до аналізу напружено-деформованого стану (НДС) моделі підземної споруди дає змогу коректно визначити розрахункові параметри, які дозволять максимально наближено апроксимувати реальну підземну споруду.

Для збільшення ефективності використання базальтового армування досліджено спосіб введення окремих стрижнів в пошкоджений шар грунту, який перебуває під навантаженням. Такий спосіб підсилення запропоновано використати під час реставрацї Варязьких печер Києво-Печерської лаври, які отримали численні пошкодження у вигляді вертикальних та похилих трішин стелі і стін з вивалами грунту.

ключові слова: реставрація історичних об’єктів, базальтова арматура, грунтова модель ділянки печери, фізична нелінійність, скінченно-елементна модель.

\section{Introduction}

The underground space, where there are historical structures of the Kyiv Pechersk Lavra (Near, Far and Variazhski caves) is constantly exposed to active environmental influences. Neutralization of the influence is significant difficulties due to tight operating conditions and the need to carry out restoration work under permanent loads.

Variazhski caves are part of the Far Caves of the Lavra (Kyiv, Ukraine). Cave passages dug in a layer of browngray and brown-yellow Poltava sandstone. The thickness of the sandstone layer varies from $2-3$ to $6-8 \mathrm{~m}$. Poltava sandstone overlaps the sands of the Kharkov Formation, represented in the cave area with greenish-gray glauconite fine-grained sands, partially loam and sandy loam. The thickness of the sand layer ranges from 1-2 to 5-8 m.

The current state of Variazhski caves can be called critical. In connection with $100 \%$ air humidity and the lack of basic care in the dungeons in recent years, more than ten large and small landslides of sections of walls and arches of caves have occurred [1,2]. Most of them occur due to the progressive destruction of materials [3, 4].
A similar situation is observed in certain areas of the Near and Far Caves. However, due to regular maintenance and local reinforcement, emergency damage was localized. Some sections of the Far Caves: the Church of the Nativity of Christ and the exit corridor from the caves were reinforced by reinforcing the inner surface of the soil vaults with nets from basalt reinforcement [5, 6]. On the basis of the Kyiv National University of Construction and Architecture (KNUCA), to confirm the effectiveness and in order to study the features of the specified amplification method, numerical and experimental studies [7] of the soil model of a fragment of the cave passage built on a scale of 1:1 are carried out. It should be noted that the questions the use of non-metallic rods for reinforcing concrete products has been repeatedly raised in publications of domestic authors [8, 9].

The results of tests and non-linear calculation of the finite element model of the structure confirmed the effectiveness of using meshes with basalt reinforcing bars as elements for strengthening the soil arch.

However, given the significant geometric heterogeneity of Variazhski caves, the great complexity of restoration in difficult and dangerous conditions, as well as the requirement to preserve the authenticity of the 
object, the use of reinforcing meshes becomes impossible. Therefore, it is relevant to study the modified methodology for strengthening basaltic reinforcement considered in the article by replacing the nets with individual rods, anchoring into the soil mass using an adhesive mixture. Similar methods of amplification are found in the literature only for above-ground, in particular, stone structures [10].

Thus, the object of research is the soil model of the cave site, which approximates part of the underground structure of the Kyiv Pechersk Lavra (Kyiv, Ukraine). And the aim of research is determination of the behavior of the soil model of a fragment of the cave passage with defects such as cracks, reinforced by individual basalt reinforcing bars, under the action of a static load.

\section{Methods of research}

Experimental studies were conducted on a prototype, which for seven years was in the open air under the influence of the environment, which caused significant damage (Fig. 1):

- development of the root system due to the germination of plants on the curved arch;

- deep soil perforation by insects from all sides of the model;

- erosion of the soil by precipitation.

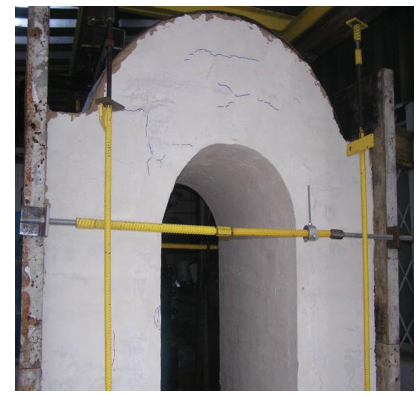

$a$

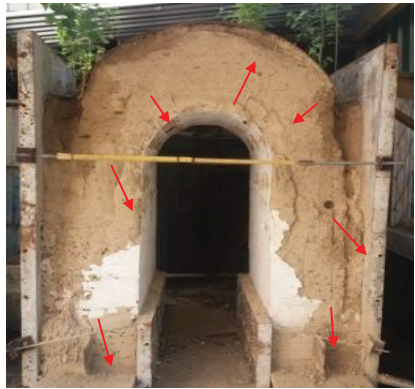

Fig. 1. Soil model of a fragment of the cave passage: $a-2012 ; b-2019$

The condition of the sample was assessed as unsuitable for normal operation, has a stable tendency to emergency, due to:

- losses of about $30 \%$ of the cross section;

- destruction of the arched part by tree roots;

- through small-scale massive damage to the base with a diameter of $4-5 \mathrm{~mm}$.

The tests were carried out in two stages - the first was to determine the residual bearing capacity of the model after a seven-year stay in the open air. The load of the sample occurred until $1 / 10$ of the distance between the points of fastening from the plane of the exposed vertical rod of the lattice of the reinforcing cage bending (Fig. 2).

When the value of the limit bending of the rod $(1.2 \mathrm{~cm})$ was reached, the loading of the sample was stopped and the soil mass, which was in a stressed state, was strengthened by additional, inclined basalt rods, not connected with the reinforcing cage. Rods with a diameter of $10 \mathrm{~mm}$ and a length of $300 \mathrm{~mm}$ were installed in the middle of the interior of the model in two rows with a pitch of $240 \times 120 \mathrm{~mm}$. To exclude from the work a pre-installed frame, the vertical rods of the mesh were cut.

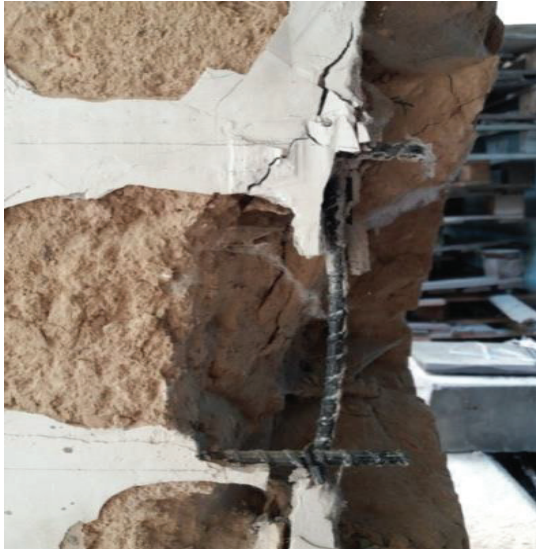

Fig. 2. Ultimate bending of the rod $(1.2 \mathrm{~cm})$

After amplification was completed, the loading process was continued. The condition for stopping the experiment was determined by two criteria: either the appearance of signs of destruction of the model, or achievement by the load of the values maximum permissible for the power equipment of the stand.

Simultaneously with full-scale tests, a numerical study of the elemental model of the experimental sample, modified in accordance with the given scheme, was completed. Static analysis of the structure was performed in a physically nonlinear formulation using the Lira CAD system, based on the use of the finite element method.

Approximation of the soil massif was performed using spatial 8-node finite elements of type No. 276. Reinforcing bars are approximated by rod finite elements. The limiting kinematic conditions (fixing) were adopted in accordance with the model parameters, and was tested: lateral faces were fixed from horizontal movements along the «X» axis; supporting ends were rigidly restrained.

\section{Research results and discussion}

During field tests of the first stage of the experiment, the appearance and opening of new hairline cracks in the main soil mass, as well as the gradual bending from the plane of the extreme rods of the reinforcing mesh that were not unfastened by the soil, were observed. When the value of the limit bending of the rod reached $1.2 \mathrm{~cm}$, the loading of the sample was suspended. The recorded value of the total vertical load was $11.8 \mathrm{tf}$ or $3.5 \mathrm{tf} / \mathrm{m}^{2}$.

At the second stage, after the introduction of additional basalt reinforcement rods into the soil mass, the tests were continued by gradually loading the model to a value of $17.5 \mathrm{tf}\left(5.6 \mathrm{tf} / \mathrm{m}^{2}\right)$. A further increase in load caused damage to the power equipment of the stand. In this case, new deformations and damage on the surface of the soil mass are not recorded.

The results of a numerical analysis of the mathematical model of the sample (Table 1 ) by the criterion of vertical displacements (along the $Z$ axis) also confirmed the increased rigidity of the reinforced model.

The maximum values of displacements of the nodes of the finite element model nodes in the presence of amplification are almost three times less than in the initial model. In addition, the forms of deformations are significantly different (Fig. 3). 
Table 1

Extreme displacements of finite element model nodes (FEM)

\begin{tabular}{|c|c|c|c|c|}
\hline \multirow{2}{*}{ Parameters } & \multicolumn{2}{|c|}{ Model without reinforcement } & \multicolumn{2}{c|}{ Model with reinforcement } \\
\cline { 2 - 5 } & positive & negative & positive & negative \\
\hline$\Delta x, \mathrm{~mm}$ & 7.11 & -7.35 & 9.1 & -9.42 \\
\hline$\Delta y, \mathrm{~mm}$ & 12.3 & -12.3 & 7.03 & -5.66 \\
\hline$\Delta z, \mathrm{~mm}$ & - & -99.5 & - & -30.1 \\
\hline
\end{tabular}

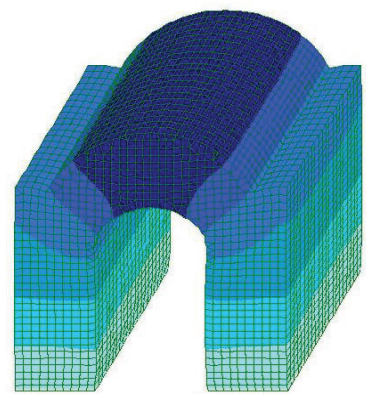

$a$

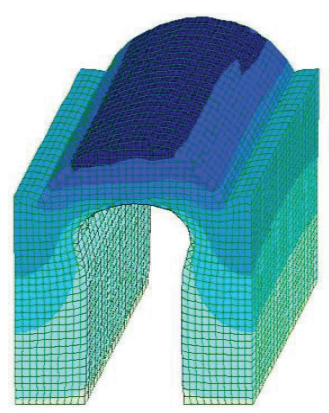

b
Fig. 3. Forms of deformation of the finite element model nodes (FEM): $a$ - without reinforcement; $b$ - taking into account reinforcement

\section{Conclusions}

During field tests of the soil model, sections of the cave approximating part of the underground structure of the Kyiv Pechersk Lavra, the features of the work of two options for strengthening basaltic reinforcement with grids and individual inclined rods were first identified.

The results of field and numerical studies have confirmed the effectiveness of the use of individual basalt rods, anchored into the soil mass on adhesive mixtures, as reinforcing elements of underground structures such as artificial caves. The obtained data may be interesting for organizations and specialists specializing in the restoration and strengthening of architectural monuments.

\section{References}

1. Kolpakova, V. M. (2012). Doslidzhennia pechernykh kompleksiv Kyievo-Pecherskoi Lavry. Lavrskyi almanakh: Kyievo-Pecherska Lavra v konteksti Ukrainskoi istorii ta kultury, 27 (10), 376.
2. Cherevko, I. (2017). Doslidzhennia vplyvu hidroheolohichnykh umov na stan zberezhennia pidzemnykh kompleksiv na prykladi Blyzhnikh pecher Kyievo-Pecherskoi Lavry. Osoblyvosti monitorynhu pamiatok arkhitektury, 72-85.

3. Romanchenko, O. D. (2018). Problemni pytannia zberezhennia Variazkykh pecher. Problemy zberezhennia ta vykorystannia istorychnykh pidzemnykh kompleksiv $i$ umovakh nehatyvnykh tekhnohennykh vplyviv. Natsionalnyi zapovidnyk «Chernihiv Starodavnii», 73-83.

4. Starostenko, V. I., Antoniuk, A. E., Demchishin, M. G. et. al (2011). Problemy sokhraneniia arkhitekturnogo naslediia istoricheskogo centra Kieva v usloviiakh vozrastaiuschego ekologotekhnologicheskogo riska. Geofizicheskii zhurnal, 33 (6), 3-11.

5. DSTU B V.2.7.-312:2016. Armatura nemetaleva kompozytna bazaltova periodychnoho profiliu. Available at: http://online.budstandart.com/ru/catalog/doc-page.html?id doc $=65007$

6. TU U V.2.7-25.2-34323267-001:2009. Armatura nemetaleva kompozytna bazaltova periodychnoho profiliu. Available at: http://online.budstandart.com/ua/catalog/doc-page.html?id doc $=26947$

7. Bielov, I. D., Vabishchevych, M. O., Diedov, O. P. (2015). Kompleksne rishennia po vidnovlenniu tekhnichnoho stanu pidzemnoi tserkvy Rizdva Khrystova Sviato-Uspenskoi KyievoPecherskoi Lavry. Novi tekhnolohii v budivnytstvi, 29, 10-29.

8. Klimov, Yu. A., Vitkovskyi, Yu. A., Soldatchenko, O. S. (2011) Vykorystannia nemetalevoi kompozytnoi armatury dlia armuvannia betonnykh konstruktsii. Budivelni materialy, vyroby ta sanitarna tekhnika, 42, 13-17.

9. Mason, J. A., Bruce, D. A. (2001). Lizzi's Structural System Retrofit with Reticulated Internal Reinforcement Method. Transportation Research Record: Journal of the Transportation Research Board, 1772 (1), 107-114. doi: http://doi.org/10.3141/1772-12

10. Di Ruocco, G. (2016). Basalt fibers: the green material of the XXI-century, for a sustainable restoration of historical buildings. VITRUVIO - International Journal of Architectural Technology and Sustainability, 1 (2), 25-39. doi: http://doi.org/ 10.4995/vitruvio-ijats.2016.6984

Belov Igor, PhD, Associate Professor, Test Center for Building Structures, Kyiv National University of Construction and Architecture, Ukraine, e-mail: vcbk@ukr.net, ORCID: http://orcid.org/00000002-5832-7036

Vabischevich Maksim, PhD, Department of Structural Mechanics, Kyiv National University of Construction and Architecture, Ukraine, e-mail: vabix@ukr.net, ORCID: http://orcid.org/00000002-0755-5186

Dedov Oleg, PhD, Associate Professor, Department of Machinery and Equipment of Technological Processes, Kyiv National University of Construction and Architecture, Ukraine, e-mail: dedovvcbk@ukr.net, ORCID: http://orcid.org/0000-0001-5006-772X 